\title{
Review-artikel: Paulus som forløber for det liberale demokrati: en trosfanatikers budskab til nutiden
}

\author{
OmTroels Engberg-Pedersen, Paulus om identitet. Hvordan er apost- \\ len relevant for os i dag?, København, Gyldendal 2020, 224 s., 250 kr.
}

Troels Engberg-Pedersens (TEP) bog om Paulus er den seneste i en lang række værker, hvor TEP på imponerende vis og med stort forskningsmæssigt overblik fremlægger sin fortolkning af Paulus. Han har samlet resultatet af mange års forelæsninger i en overskuelig bog, der er tilgængelig for både læg og lærd. Det er glimrende, selvom jeg finder det sprogligt unødvendigt at omtale Paulus som en 'lækkerbisken', at appellere til læseren om at 'holde på hat og briller' eller at møde udbrud som 'milde himmel' og om Paulus "Ih, hvor var han bekymret! Og ih, hvor blev han glad, da det viste sig at gå godt mellem dem" (s. 147). Sådanne stilistiske unoder er trættende og nedladende over for læseren. Formidling behøver ikke indebære infantilisering. Men det skal ikke skygge for bogens fortjenester. TEP kommer igennem samtlige Paulus' syv ægte breve, så de enkelte breve fungerer som prisme for særlige problemstillinger i de syv første kapitler. Han drøfter mange centrale spørgsmål i den nyeste Paulusforskning og giver sin egen stillingtagen uden direkte forskningshenvisninger.

Man har ofte kritiseret nytestamentlig eksegese for kun at fokusere på det fjerne og det fortidige i fortolkningen og lade hånt om teksternes mulige nutidsværdi. Det er en berettiget anklage, men, må man tilføje, netop denne insisteren på fremmedartethedsbesindelse har skabt store fremskridt. Det er ikke mindst opgøret med præsentismen, der har gjort det muligt at frigøre sig fra konfessionelle og andre stærke ideologiske tolkningsfiltre. I bogen vover TEP imidlertid et øje og diskuterer i det afsluttende kapitel otte Paulus' betydning for nutiden. Tilsvarende bæres bogen af en smittende glæde for Paulus, der særligt kommer til udtryk i relationen mellem TEPs identitetsfokuserede historiske Pauluslæsning og drøftelsen af Paulus' relevans i dag.

Det indledende kapitel sætter brevene og Paulus i historisk kontekst og redegør for bogens struktur. Derpå følger kapitel to og tre med fokus på Paulus' budskab. Kapitel fire og fem koncentrerer sig om en række betydningsfulde konflikter i brevene, der vedrører, hvad vi fra et fjerdeordensperspektiv kalder identitetsspørgsmål: 1) forholdet mellem judæere og hedninger; 2) slaver og herrer; 3) kvinder og mænd; 4) seksualmoral; 5) relationen mellem Kristusfællesskabet og verden udenfor. Kapitel seks drøfter forholdet mellem indhold og form i brevene. Skriftligheden er kongenial 
med Paulus' protreptisk-parænetiske formål, at drive brevmodtagerne frem mod dybere rodfæstethed i Kristusimitation og selvopgivende kærlighed til andre Kristustilhængere. I moral- og evolutionspsykologisk perspektiv ville jeg kalde det priming. Kapitel syv afslutter den historiske fremstilling af Paulus med fokus på forholdet mellem universalisme og identitetspolitik. Hvordan forholder Paulus' identitet (hans persona), som den fremskrives i brevene, sig til hans universalistiske budskab? Dermed er vejen banet for det identitetspolitiske spørgsmål i kapitel otte. Har Paulus noget at sige i den aktuelle situation med politikere som f.eks. Janša, Johnson, Kazcyński, Orbán, Salvini, og Trump? Det mener TEP, som fører drøftelsen med to Paulus-inspirerede filosoffer, primært Badiou (med fokus på universalisme) og Agamben (eskatologisk messianisme). Den afgørende diskussionspartner er dog Fukuyama, som ikke forholder sig til Paulus eller har ladet sig inspirere af ham, men til gengæld diskuterer moderne identitetspolitik, det liberale demokrati og nationalisme.

Lad denne diskussion hvile for en stund og lad os se på Paulus-læsningen. Paulus var først og fremmest trosfanatiker. Det fremhæves fem steder (s. 60. 73. 82. 100. 156). Samtidig var han trospraktiker (s. 156). Beskrivelsen dækker, hvad vi religionsvidenskabeligt betegner en karismatisk sekteriker; men der mangler dybere psykologisk og sociologisk forståelse af, hvad det betyder. TEP læser Paulus positivt og i bedste mening, men det giver undertiden læsningerne en naiv karakter, fordi TEP grundlæggende savner sans for den nidkærhed og kompromisløshed, der hører den sekteriske karismatiker til. Om sammenhængen mellem form og indhold hos Paulus hedder det:

"Hvis indholdet var et sandt fællesskab, så måtte retorikken også afspejle dette. Så kunne retorikken ikke gøre brug af propaganda eller forførelse. Den kunne heller ikke have karakter af psykisk vold ved fx at bygge på apostlens særlige autoritet og på den måde forsøge at tvinge modtagerne på plads. I stedet måtte den appellere - og appellere til brevmodtagernes egen forståelse" (s. 155).

TEP forstår, at Paulus "ikke ligefrem var beskeden" (s. 22), og betegner ham som "skånselsløs apostel" i sammenhæng med 2 Kor 10-13. Han citerer også 1 Kor 4, 16, hvor Paulus kræver modtagerne til regnskab: "Skal jeg komme til jer med stokken eller med kærligheds og mildheds ånd?" Det er svært ikke at se som psykisk vold, der hviler på Paulus' Kristuskaldelse, som han i brevene og især Gal. bruger i sin iscenesættelse af en exceptionel karismatisk autoritet. Han kalder faktisk sig selv for Guds engel (Gal 4, 14, jf. 1, 8). Det er også vanskeligt at sige ham fri for i brevene både at propagandere og søge at forføre sine modtagere. Paulus appellerer rigtignok til modtagerne og deres forståelse, men han har konstrueret den for dem og de kan kun afvise den under den forudsætning, at de fraskriver sig frelsen (i Paulus' forståelse vel at mærke). Jeg medgiver, at TEPs Pauluslæsning er smukkere og mere tiltalende end min, men den fremstår alene plausibel, fordi TEP er blind for den retoriske magtudøvelse, Paulus øver gennem brevene. Det er også tankevækkende, at TEP tager Paulus' selviscenesatte følelser for pålydende og ikke overvejer, hvordan de indgår i et retorisk spil, hvis mål er at tvinge modtagerne derhen, hvor han ønsker dem. Deri ligner han mange andre karismatikere og sekterikere gennem historien. Det er den form for totalitetskrav, Assmann har betegnet monoteismens pris, men som med fordel kan udstrækkes til at gælde kosmos- eller aksetidsreligionstypen generelt. 
Der er ikke noget overraskende i, at TEP ser en tæt sammenhæng mellem Paulus og stoicismen. Det har været grundlæggende i alt hans arbejde, selvom det ikke står helt klart, hvordan han præcist tænker relationen genealogisk. Den stoiske læsning er vigtig for TEP, fordi den idé- og religionshistorisk sætter ham i stand til at forene forskellige sider hos Paulus: jødisk apokalyptik og stoisk filosofi og, tror jeg, religiøs metafysik og moderne oplysningstænkning. Den sidste modstilling vender jeg tilbage til. Den stoiske del kommer til udtryk i Paulus' parænese eller social-moralske formaninger (TEP: Paulus' etik), der negativt skal eliminere modtagernes bundethed til forskellige lidenskaber og positivt forme deres Kristussindelag, ligesom TEP opfatter Paulus' stoflige pneuma-tanke parallelt med stoisk fysisk kosmologi (jf. s. 42f.). Den jødiske apokalyptik finder udtryk i Paulus' religiøse verdensanskuelse (TEP: Paulus' teologi). Jeg ser en stærkere forbindelse mellem de to, skønt TEP også er opmærksom på, at skelnen er kunstig (s. 17f.). Den ethos, Paulus fremkalder for modtagerne, er tænkt som Paulusimitation, der tilsvarende forstås som Kristusimitation - det hierarkiske forhold mellem karismatiker og tilhængere fastholdes.

Hos TEP er tanken, at Kristustilhængerne i dåben har fået den himmelske pneuma i sig, så de virkeliggør Kristuslivet på jord. De lever ikke for sig selv, men for de andre Kristustilhængere (Fil 2, 4, jf. Gal 6, 2). Opfattelsen kan kun fastholdes, hvis man som TEP (og i 1897 Paul Wernle) forfægter en meget bombastisk forstålse af pneumaeksistensen. TEP har ret $\mathrm{i}$, at Kristustilhængerne menes at opfylde retfærdigheden; men det er som led i en priming og ikke en realiseret, men derimod aktualiseret tilstand. Påstanden er ikke, at Kristustilhængerne virkeliggør finaltilstandens manglende mulighed for at synde (non posse peccare). Det er en kraftig opmuntring til, at de de facto handler retfærdigt, fordi der i Kristus er sket noget afgørende nyt, som den enkelte har fået del i gennem sin dåb (posse [non posse peccare]).

Det undrer mig, at TEP i sin drøftelse af stoicismen tager Paulus' peristase- eller lidelseskataloger for pålydende og ikke ser dem parallelt til den retoriske iscenesættelse af den stoiske vismand. Paulus' lidelser skal ikke tages for pålydende, men ses i lyset af den vise, som udviser udholdenhed over for lidelser, hvormed han kvalificerer sig som et skue (theatron eller spectaculum) for både Gud og mennesker (jf. 1 Kor 4, 9; Seneca Prov 1.2.9; Ep 64, 6; Epiktet Diatr 2.19.25; 3.22.58f; Plutark Alex fort virt 1, 2f.). Det er lidelser, som gør mænd til mænd, som Epiktet siger (Diatr 1.14.1). Heri ligger den retoriske dobbelthed hos Paulus, at han på en og samme tid spiller kosmosreligionens svaghedskort og netop derved gør sig sine konkurrenter og modtagere overlegen: En supersofist, om man vil. Jeg er ikke i tvivl om, at der findes stoiske påvirkninger hos Paulus, men der er også endog meget stærke platonske. Det var ikke for ingenting, at Nietzsche med fokus på Paulus kaldte kristendommen for folkeplatonisme. Den drøftelse kunne TEP med fordel været gået ind i, hvis han havde haft religionshistorisk blik for problemstillingen. For forskellen mellem jødisk apokalyptik og stoisk filosofi er ikke så stor, hvis man ser dem som varianter af kosmosreligionstypen. Derved ville han have vundet en klarere forståelse af, hvad han kalder Paulus' quasi-ethnos-religion (s. 98). Det er forskellen på byreligionens genetisk-etnisk 
funderede religion og kosmosreligionens kulturelt funderede fællesskab bundet sammen af tilslutningen til en bestemt tolkningsramme, hvilket selvsagt ikke hindrer den sidste $i$ at overtage den førstes ethnos-emblematik, men som metafor.

TEP henviser ikke til det såkaldt 'nye radikale Paulusperspektiv,' der de seneste år har fået meget vind i sejlene i navnlig amerikansk forskning. Her forstås Paulus som repræsentant for en tanke om tovejs-frelse: En for judæere (Kristustilhængere eller ej) og en anden for Kristustilhængere af hedensk baggrund. TEPs forståelse er mere nuanceret. Han understreger bestandigt, at Paulus var judæer (TEP: jøde), og at tidlig Kristusreligion var en Israel-religion (TEP: jødedom) (s. 27f. 58. 92), men samtidig fremhæver han, at der hos Paulus de facto er kritik af Moseloven, som ikke kan reduceres til et spørgsmål om brug af identitetsmarkører (omskærelse og kasruth) blandt Kristustilhængere af hedensk etnisk baggrund (s. 85. 92-97. 102). Omvendt er en formulering af typen "Jøderne måtte ikke længere tillægge Moseloven nogen religiøs betydning" (s. 102) stærkt misforståelig, fordi Paulus' grundlæggende påstand er, at Kristusreligionen er Moselovens opfyldelse, som hans brug af skriftcitater med al tydelighed dokumenterer. Moseloven har opnået sin fuldkommenhed (telos - og ikke som i den autoriserede fejlagtige 92-oversættelse "Kristus er enden på loven") i Kristus (Rom 10, 4). Derfor opfylder Kristustilhængerne nu (som aktualisering og ikke realisering!) lovens rette orden (dikaiōma), fordi de vandrer efter ånden og ikke kødet (Rom 8, 4). Moseloven per se var ikke tilstrækkelig til at sikre dette. Den har nået sin fuldbyrdelse i Kristusreligionen, hvor ånden har gjort det muligt for Kristustilhængerne i handling at opfylde Moselovens grundlæggende tanke, nemlig at elske sin næste som sig selv (Rom 13, 8, jf. Gal 5, 14), fordi kærligheden er lovens fylde (plērōma nomou) (Rom 13, 10). Det er ikke klart, om TEP tænker denne kærlighed generelt rettet mod alle mennesker eller som alene orienteret mod Kristusgruppen. Igen ville TEP med fordel have kunnet nuancere sin forståelse ved at se den i sammenhæng med kosmosreligionen. Tanken om den indre over for den ydre omskærelse (Rom 2, 25-29, jf. Gal 5, 6) og den indre judæer over for den ydre er en pointering af, at Moselovens sande opfyldelse er i ånd og ikke i kød. Jeg kunne også godt have ønsket mig en klarere begrebsbrug, hvor udtryk som 'jøde', 'jødedom' og 'kristendom' er misvisende, fordi de falder tilbage i en tradition, hvor man tolker en tidligere situation ud fra senere tids modsætninger, så læsere fejlagtigt må tro, at størrelser som 'jøde', 'jødedom' og 'kristendom' allerede fandtes hos Paulus. Det gjorde de ikke.

Jeg er også skeptisk over for TEPs gennemgående oversættelse af pistis-leksemet med 'tro'. Det er en oversættelse, der ikke argumenteres for, skønt der de seneste år har været rettet voldsom kritik mod den, fordi pistis, pistos og pisteuein først på et langt senere tidspunkt får betydningen 'tro' og 'tro på'. Hos Paulus betyder det 'trofasthed', 'trofast' og 'investere sin trofasthed hos', hvilket er noget andet. Jeg antager, at TEPs grund til at fastholde den traditionelle oversættelse er hans vægtlægning af et kognitivt aspekt og hans interesse i at forbinde Paulus tæt til den filosofiske tradition, jf. også den gentagne tanke om Paulus som 'trosfanatiker', der også er vigtig for ham i drøftelsen af Paulus' relevans i dag. Pistis er for TEP tro på nogen og noget, men det er svært at se, at der skulle være filologisk dækning for det på græsk, latin, 
hebraisk, aramæisk eller koptisk på dette tidspunkt - en større komparativ undersøgelse af øvrige oldtidssprog er i den grad påtrængende. Selvsagt er der et kognitivt aspekt involveret (det er netop trofasthed rettet mod Kristus og ikke andre former for Israel-religion), men det afgørende element drejer sig om den følelsesmæssige forbundethed, der følger af at stå i et bestemt forhold, en pagtsrelation, om man vil. Det er det primære i Paulus' og hans samtids brug af pistis-leksemet, ligesom, vil jeg hævde, det gælder for religion generelt; men det forudsætter, at man lægger en religionsdefinition og -teori på bordet, så man kan se den pågældende forsker i kortene og ikke skal rekonstruere den intuitive forståelse, der ligger bag opfattelsen. Når det gælder oversættelser og forståelse, kan man diskutere en række tekster som f.eks. at 2 Kor 3, 6 skulle dreje sig specifikt om Moseloven (s. 67 - det er vel primært en subtil hudfletning af Paulus' modstandere, der identificeres med den gamle pagt), at 2 Kor 4, 5f. skulle gælde Paulus' kaldelseserfaring (s. 27 - gælder det ikke snarere den stillingtagen, brevmodtagerne her og nu kaldes til regnskab for, der er metaforisk at forstå som nyt skabelseslys?), eller at 2 Kor 5, 16 skulle vedrøre den jordiske Jesus (s. 38 - mon ikke snarere det vedrører en kødelig forståelse af Jesus); men det ændrer ikke ved, at bogen er suveræn i forhold til den helstøbthed med hvilken, TEP gennemfører sin fortolkning. Den ægger til nytænkning og udfordrer med klare tolkninger.

Afslutningsvis ser jeg på TEPs drøftelse af Paulus' nutidige relevans. TEP er ontologisk naturalist og gør det klart, at ingen oplyste mennesker i dag kan abonnere på Paulus' metafysiske verden (s. 11. 39f. 74f. 122. 189). Det er jeg enig i; men spørgsmålet er, om mennesker i antikken som i dag kun abonnerer på en ontologi. Det tvivler jeg på, selv om jeg dermed ikke har sagt, at der ingen ontologiske forskelle er i forståelse mellem antikken og moderne, vesterlandske akademikere. Men jeg er overbevist om, at ontologier ofte essentialiseres i et omfang, så man ikke i tilstrækkelig grad tager menneskers situationsbestemte pendulering mellem forskellige repræsentationer med dertilhørende forskellige ontologiske implikationer alvorligt. Eller sagt på anden vis: Mennesker har altid oscilleret mellem forskellige virkelighedsforståelser afhængigt af de specifikke situationer, de har befundet sig i. Denne drøftelse viser, at TEP først og fremmest tænker religion som bestemte ideer med et propositionelt indhold, jf. min tidligere pointering af den underliggende religionsopfattelse. Nogle må vi give afkald på, fordi det er bedaget og hører et forsvundet verdensbillede til, mens andet kan fastholdes. Og det er her, Paulus' etik kommer ind.

Paulus har "et brandaktuelt budskab til os i dag" (s. 76), hvor han viser sig flere moderne tænkere overlegen. På to punkter ligner Paulus' løsning for sine menigheder Fukuyamas løsning på det moderne liberale demokratis problemer, men på et afgørende punkt fører Paulus drøftelsen videre. For Paulus består troen (parallelt med Fukuyamas tanke om national identitet som en creed) på, at Jesus Kristus er Guds søn, at han er korsfæstet og opstanden og at alle Kristustilhængerne er et i Kristus religionsvidenskabeligt kunne man med Rappaport betegne det som systemets grundlæggende ultimate sacred postulates, eller USP'er. På næste niveau gælder det for Paulus - parallelt med Fukuyamas forståelse af en nationalidentitets-creed - at Kristustilhængernes creed er uafhængig af etnicitet, køn, status og andre skelsættende identiteter (jf. Gal 3, 28). Forskellen opstår på det tredje niveau, hvor Fukuyama 
nøjes med at anerkende eksistensen af forskellige identiteter under de to øvre niveauer, mens Paulus omvendt forsøger at tænke dem sammen. Han anerkender ikke blot eksistensen af forskellige identiteter, men åbner mulighed for, at de kan udleves, så længe de ikke gør vold på eller skader de to øvre niveauers USP'er. Man kan leve som judæisk Kristustilhænger så længe, man ikke derved skader andre Kristustilhængere. Det samme gælder i forhold til diskussionen om afgudsofferkød i 1 Kor 810, hvor de stærke udmærket kan fastholde deres sociale identitet, der indebærer frihed til at spise afgudsofferkød så længe, de ikke derved gør skade på deres svage brødre. De skal netop aldrig tænke på deres eget, men først og fremmest de andre vel (Fil 2, 4). I denne altruistiske maksime ligger ifølge TEP også kernen i det moderne liberale demokrati, der derved ikke blot har rødder i oplysningstiden men også hos Paulus. Men TEP går afslutningsvis unægtelig et betydeligt skridt videre. Hvis Paulus åbner for anerkendelse af forskelle eller supplerende identiteter, som TEP kalder det, under en fælles liberal oplysningsbaseret demokratisk creed, kan Paulus' altruistiske idé gøres til 'direkte pejlemærke' for nutiden (s. 212). Ja, mere end det. TEP er idealistisk metafysiker. Han hævder ligefrem, at der er historisk belæg for noget sådant $\mathrm{i}$ en "særlig dansk national identitet," og at det er, "hvad vi danskere egentlig vil" (ibid.) Samtidig kan man ifølge TEP på baggrund af Fukuyama se, hvordan "lige præcis denne tanke tillige udgør den bedste løsning på et grundlæggende problem her og nu om identitetspolitik og demokrati i vores og andres liberale demokratier: Hvordan skal forskellige grupper i samfundet anerkendes med hver deres egen identitet, samtidig med at vi alle lever i et forpligtende fællesskab?" (ibid.). Det er jo meget godt, men det forekommer mig nu alligevel en kende blåøjet.

Hos TEP løses problemer ved, at mennesker tilslutter sig bestemte ideer, der lærer dem deres fejltagelser og hjælper dem til at forbedre sig. Det er en idealistisk metafysik, der vil noget. Den fremstår ligeså problematisk som en materialistisk metafysik, der reducerer spørgsmålet om menneskelig adfærd til kognitive dispositioner eller socio-materielle forhold. Diskussionen ignorerer menneskets grundlæggende biologi, det miljø, det befinder sig i, og den psykologi, det er udstyret med. Hvis man som TEP også vil søge løsninger på nutidens store spørgsmål, virker det naivt at tro, at det blot drejer sig om at forandre mennesker gennem bestemte ideer. Som kultur er ideer vigtige, men deres gennemslagskraft må drøftes i sammenhæng med forskellige selektionsmekanismer - biologiske, biokulturelle og sociale - som determinanter for menneskelig evolution. Andet er utroværdigt. Jeg synes ikke mindst, det er i den sammenhæng, Paulus er interessant, fordi hans breve netop vidner om en ny kulturdannelse afstedkommet af markante socio-materielle og kulturelle ændringer i hans og den tidlige Kristusbevægelses miljø. Det er en vægtig diskussion, TEP slet ikke går ind i. Disse kritikpunkter ændrer imidlertid ikke ved vigtigheden af bogen. Både som Paulus-analyse og som et bud på hans relevans i dag er bogen en intellektuel præstation, der som her inspirerer, udfordrer og kalder på kritik.

Anders Klostergaard Petersen, lektor Afdeling for Religionsvidenskab, Aarhus Universitet. 